\title{
Bardet-Biedl and Alström syndromes in Spain
}

\author{
D Valverde*, T Piñeiro-Gallego, I Pereiro \\ From First International Cilia in Development and Disease Scientific Conference (2012) \\ London, UK. 16-18 May 2012
}

Bardet-Biedl (BBS, OMIM 209900) and Alström (AS, OMIM \#203800) syndromes belong to a group of heterogenic disorders called ciliopathies where alterations on the cilia and the ciliary mechanisms are implicated. The genetically heterogeneous nature of BBS, with fifteen genes identified (BBS1-BBS15) to date, is also shown in the considerable inter- and intra-familial variation in the phenotype. Mutation screening of the involved genes has resulted in the identification of approximately $70 \%$ of the causative mutations, indicating that additional BBS genes have to be identified. ALMS1 is the only gene associated with the development of AS. ALMS1 encodes a novel protein, widely expressed and with unknown molecular function. We recruited 81 BBS families with 105 affected patients (44 females/ 61 males) and 5 AS families with 5 patients (4 females/ 1 male). Molecular analysis was performed using three strategies: homozygosity mapping when the family was consanguineous, BBS genotyping chip (Asper Ohthalmics), and direct sequencing. We were able to detected at least one mutation in $47 \%$ of the BBS patients. The allelic implication for the major genes in our patients was as follows: $B B S 1$ (56\%), BBS10 (20\%), BBS12 (11\%), BBS6 (7\%), BBS3 (4\%), BBS2 (1\%) and BBS5 (1\%). In AS patients we could detect the two responsible mutations in two families, and only one mutation in heterozygous state in a third family. The molecular study of these syndromes can be very helpful in providing a diagnosis in this patients, hence appropriate genetic counselling for families and adequate medical follow-up for affected children.

Published: 16 November 2012

Submit your next manuscript to BioMed Central and take full advantage of:

- Convenient online submission

- Thorough peer review

- No space constraints or color figure charges

- Immediate publication on acceptance

- Inclusion in PubMed, CAS, Scopus and Google Scholar

- Research which is freely available for redistribution
() Bïmed Central

\footnotetext{
* Correspondence: dianaval@uvigo.es
} University of Vigo, Spain 